\title{
THE ANTECEDENT OF REGIONAL FINANCIAL REPORT QUALITY
}

\author{
Slamet Widodo $^{1 *}$, Akram Harmoni Wiardi ${ }^{2}$, and Tri Deni Prabowo ${ }^{3}$ \\ 1,2,3 Universitas Bengkulu, Bengkulu, Indonesia
}

\begin{abstract}
The objective of this research is to analyze the competency, the comprehension of the government accounting standard, the implementation of internal control system and the quality of financial report in Kepahiang Regency.This Research was done to financial managers. The data were gathered by distributing the questionnaire to 102 respondents. This study used the data analysis of Multiple Linear Regression. The result of this research showed that competency has significant effect on the quality of financial report. The comprehension of the government accounting standard has significant effecton the quality of financial report. The implementation of internal control system significant effect on the quality of financial report.
\end{abstract}

Keywords: Accounting Standard, Competency, Internal Control, Quality

\section{INTRODUCTION}

Government as the largest public sector organizations take full responsibility for improving the welfare of the people, uphold the wishes of the people, sustainable development and social justice, runs the functional aspects of an efficient and effective government that can be tangible good governance. As one form of accountability in the implementation of government presented in the financial statements set forth in Law No. 17 of 2003 on State Finances and Law No. 32 of 2004 on Regional Government. The financial statements are presented to stakeholders to assist with higher quality decision making.

Financial Quality statements are the financial statements which have the characteristics of relevant, reliable, comparable and understandable so as to provide useful information for the consumer (Sudiarianti et al. 2015). Assessment of the quality of Local Government Financial Statements (LKPD) is conducted by the State Audit Board (BPK) by conducting annual audits. The results of the BPK assessment are expressed in 4 (four) opinion forms that are unqualified (WTP) including unqualified with explanatory paragraph (WTP-DPP), fair with exception (WDP), unreasonable (TW) and no opinion (TMP) . Fair representation is expressed in the form of opinion by considering the criteria of conformity of financial report with Government Accounting Standard (SAP), adequacy of disclosure, compliance with statutory regulations, and effectiveness of internal control (Indriasih, 2014).

Local Government Financial Statements in Kepahiang District in 2015 has received the title of WTP by the CPC, but there are still weaknesses that become records should be corrected, examination findings include:

1. Taxes on routine expenditures and activities on the four Work Units within the Kepahiang Regency Government have not been collected for remittance to the state treasury;

2. The accountability report for the transfer of financial aid for the allocation of village funds has not been submitted to the regional head;

3. Errors of budgeting of goods and services expenditure in the form of procurement of subsidized nine basic necessities at the Department of Cooperatives, SMEs and Trade Industry;

\footnotetext{
* Corresponding author. Email address: swidodo@unib.ac.id
} 
4. There is an asset of equipment and machinery at the regent's official house and the vice regent's office home kepahiang that is not mastered.

The problems faced by the current local government is low competencies of financial managers and limited eo financial expert. It also became a phenomenon as a major problem of local governments in Indonesia (Hyacinth, et al., 2008). According to Wibowo (2014), the success of an organization is achieved by strong foundation of human resources competencies. Competency is an ability to perform or perform a job or task based on skills and knowledge and supported by the work attitude required. Competencies indicates a skill or knowledge characterized by professionalism in a particular field as the most important (Wibowo, 2014). According to Bastian (2001) qualified financial statements can not present by itself. A financial report quality can not be separated from good governance of financial management. Good financial governance is an early reflection that financial reporting is also good. Competence financial manager can be interpreted as a financial manager who has the competencies to present good quality of financial reports.

The Government publishes the government accounting standards established by Government Regulation No. 71 of 2010 which will be used to produce a reliable financial statement which can be the basis for decision making and is expected to become a reference and standard application. The central government, local governments and organizational units within the central / regional government are obliged to present financial statements in order to create more accountability and transparency of financial management. The understanding of government accounting standards is required in the preparation of financial statements. First is the conversion from the cash basis points to accrual basis guided by the PP 71 of 2010 which requires the financial management staff who understand very well the logic of accounting and government accounting standards. Halim and Kusufi (2014) stated that financial managers in preparing financial statements should understand government accounting standards. According to Fikri et al. (2015) a good understanding of government accounting standards by financial managers in regional work stations will certainly improve the quality of financial statements. Financial managers who already have an understanding of government accounting standards mean that they are able to understand the established accounting principles and able to apply the accounting standards in preparing and presenting government financial reports so as to produce quality financial reports.

In addition to improve the quality of financial statements, the financial managers required the implementation of internal control system. According to Arens et al. (2008) the application of effective internal financial controls can improve the quality of financial statements. So that the financial manager must be able to apply effective internal control system in order to produce quality financial reports. With the enactment of Government Regulation No. 60 of 2008 on Government Internal Control System (SPIP) which states that the purpose of Government Internal Control System is to provide adequate assurance for the achievement of effectiveness and efficiency in achieving the objectives of state administration, the reliability of financial statements, and the safeguarding of state assets. Based on the phenomenon and the research background we analyze:

1. How is the description of competence, the understanding of government accounting standards, the implementation of internal control system and the quality of financial statements in Kepahiang Regency

2. How is the influence of competence, understanding of government accounting standards and the application of internal control system to the quality of financial statements in Kepahiang Regency 


\section{LITERATURE REVIEW AND HYPOTHESES DEVELOPMENT \\ 1. Quality of Financial Statements}

The financial statements are the representation of financial information also serves as a means of accountability and evaluation of financial performance (Mahmudi, 2016). John et al. (2007) defines financial reporting is the process of communicating the company's financial accounting information to external parties. According to Law No. 17 of 2003 on State Finance (article 30-32), the government's financial report is the responsibility of state finance management by the President as the head of government and the holder of state financial management authority as well as the governors / regents / mayors as the holders of financial management power area. Government financial reports covering Central Government Financial Report (LKPP) and Local Government Financial Report (LKPD) are prepared under SAP.

The general purpose of the financial statements according to Government Regulation No. 71 of 2010 is that government financial reporting should provide useful information for users in assessing accountability and making decisions in economic, social and political decisions by:

a. Provide information about the source, the allocation and use of financial resources;

b. Provide information on the adequacy of current receipts to finance all expenditures;

c. Provide information on the amount of economic resources used in the activities of reporting entities and the results achieved;

d. Provides information on how the reporting entity is funding all of its activities and sufficient for its cash needs;

e. Provide information about the financial position and condition reporting entity related to the source - the source of acceptance, both short and long term, including those derived from taxation and borrowing;

f. Provides information on the changes in the financial position of the reporting entity, whether increased or decreased, as a result of activities carried out during the reporting period.

The quality of financial reporting is complete and transparent information, designed not to mislead users (Jonas \& Blanchet, 2000). Biddle et al. (2009) describes the quality of financial statements is the accuracy of financial statements that provide information on the performance of the company, especially cash flow capital investors are expected. Tang et al. (2008) states that financial statements provide true and reasonable information on performance and financial position.

Hilton (2011) suggests the characteristics of information determine its usefulness in decision making are: (1) Relevant Information, (2) Accuracy (3) Timeliness. Relevant and accurate data is only valuable if it is timely, that is, available in time for a decision. Based on Government Regulation No. 71 of 2010 on Government Accounting Standards that the characteristics of financial statements are normative measures that need to be manifested in accounting information so as to meet its objectives. Beest et al. (2009) indicates that qualitative characteristics are valid and reliable measures to assess the quality of financial statements. The following four characteristics are a necessary normative prerequisite for government financial reports to meet the desired quality:

1. Relevant information, the information contained in it, can influence user decisions by helping them evaluate past or present events and predict the future, as well as correcting their evaluation results in the past.

2. Reliably, the information in the financial statements is free of misleading notions and material errors, presenting every fact honestly, and verifiable. Reliable information meets the following characteristics:

3. Can be compared, ie information contained in the financial statements will be more useful if it can be compared with the previous period financial statements or financial statements of other reporting entities in general. 
4. Understandable The information presented in the financial statements can be understood by the user and expressed in terms and terms tailored to the limits of the user's understanding.

\section{Competency}

According to Hitt et al.(1999) competency is a combination of knowledge, skills, attitudes and experience. Explanation of the same competence is also expressed by Wibowo (2012) Competence is an ability to perform or perform a job or task based on skills and knowledge and supported by work attitude demanded by the work. Hutapea and Thoha (2008), revealed that there are three main components of the formation of competence, namely: Knowledge, Skills, and Behavior.

\section{Comprehension of The Government Accounting Standard}

Understanding Government Accounting Standards, is able to distinguish, present and define accounting transactions according to government accounting standards. Mahmudi (2010) states that the government accounting standards contain accounting principles applied in preparing and presenting financial statements to government organizations.Based on Government Regulation No. 71 of 2010, government accounting standards are the accounting principles adopted in preparing and presenting government financial reports. Transactions in accordance with government accounting standards are revenue recognition, expense recognition and depreciation of property and equipment (Tanjung, 2013).

\section{Implementation of Internal Control System}

The implementation of the internal control system is an integral process for the actions and activities undertaken continuously by the leadership and all employees to provide reasonable assurance on the achievement of organizational goals through effective and efficient activities, reliability of financial reporting, security of state assets and compliance with laws and regulations. Internal controls are designed and implemented by management to be reasonable ensure organizational objectives will be achieved (Arens et al., 2008). Elements of internal control applied in the government according to Government Regulation no. 60 of 2008 consists of elements: (1) the control environment, (2) risk assessment, (3) control activities, (4) information and communication and (5) monitoring.

\section{Development of Hypotheses}

According Sekaran (2010) research hypothesis is an initial suspicion / interim conclusion of the relationship influence between independent variables to the dependent variable before the research and must be proven through research. Qualified financial statements should have the qualitative characteristics required as mentioned in the government conceptual framework (Government Regulation No. 71 of 2010) including: relevant, reliable, comparable, and understandable information. According Wahyono (2004) competence of human resources play a role in generating information of value (reliable). Based on research conducted Anggun (2016) shows that the competence of human resources positively affect the quality of local financial statements.

Accounting standards which the government is a guide to be able to present the financial statements qualified as a form of government responsibility for financial management (Nuraini \& Sumiyati, 2014). Financial managers to develop quality financial statements should understand government accounting standards (Halim \& Kusufi, 2014). Research conducted by Sari et al. (2014) states that there is a positive and significant influence on the understanding of government accounting standards on the quality of local government financial statements 
Research conducted Nuryanto and Afiah (2013) states internal control affects the quality of financial statements. Princess et al. (2016) indicates that the implementation of internal control system has an influence on the quality of financial reporting. Based on the reviewd literature, we finally propose the following Hypothesis.

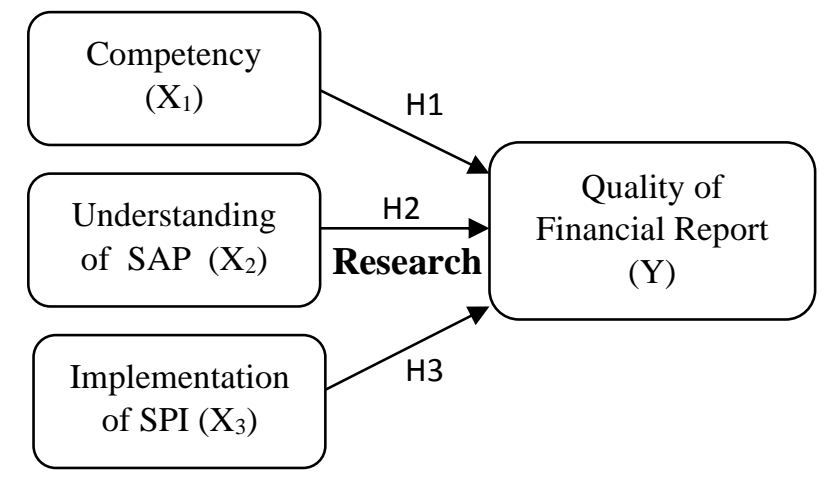

Source: adapted from Sari et al. (2014) and Princess et al. (2016)

$\mathbf{H}_{1}$ : competence, understanding of government accounting standards and the implementation of internal control systems simultaneously significant effect on the quality of financial reporting.

$\mathbf{H}_{2}$ : Competence significant effect on the quality of financial reporting.

$\mathbf{H}_{3}$ : Understanding government accounting standards significantly influence the quality of financial reporting.

$\mathbf{H}_{4}$ : The implementation of internal control systems significant effect on the quality of financial reporting

\section{RESEARCH METHODOLOGY}

\section{Population and Sample}

The population in this study is the finance managers who works at the regional government office in Kabupaten Kepahiang, Bengkulu Province. Furthermore, according to Sugiono (2015) the sample is part of the number and characteristics possessed by the population. We operate purposive sampling technique to obtain primary data. Respondents in this study were 1) Financial Administration Officer Regional Work Units 2) Spending Treasurer 3) Financial Management staff. The sample size is 130 respondent that works in the Financial Administration Officer Regional Units (50 resondent), Spending Treasury Officer (30 respondent), and Financial Management staff (50 respondent). The Respondents are the officer that has been worked for 2 years minimum at regional government office. We distribute 130 questionnaire to the respondent and obtain 102 processable questionnaire, the rest of it were not returned.

\section{Data Collection}

The data of this research are primary data. The data collected by this approach is done through survey method. According Zikmund (2010) survey research method is a form of research techniques in which information is collected from a sample of people, through questions. The survey in this study used questionnaires as the instrument of data collection. The goal is to obtain information needed in this study regarding the responses of respondents about competence, understanding of government accounting standards, implementation of internal control system and quality of financial statements on regional work stations in Kepahiang Regency. 


\section{Variable}

The dependent variable of this study is the quality of financial statements. The financial statement quality variable consists of four dimensions: relevant, reliable, comparable and understandable. Independent variables from this research are:

1. Competence consists of three dimensions: knowledge, as well as the inability to conduct

2. The understanding of Government Accounting Standards consists of three dimensions: distinguishing revenue recognition, presentation of the recognition of expenses and determine the depreciation of fixed assets

3. Implementation of Internal Control System consists of five dimensions: Environmental control, risk assessment, control activities, information and communications, and monitoring

\section{RESULTS AND DISCUSSION}

1. Test Validity and Reliability

There are two types of construct validity, namely convergent and discriminant validation. According to Sekaran (2010), convergent validity is a way of measuring scores with two different instruments in measuring the same concept showing a high correlation, whereas discriminant validity is a way of measuring the score of two predicted uncorrelated variables and the score obtained by measuring it is completely evident empirical. Based on the types of validity, we apply the convergent validity in this study. The result of validity test for competence correlation value is in the range of 0.603 to 0.819 , SAP understanding in the range of 0.502 to 0.797 , SPI application in the range of 0.515 to 0.930 , and Financial statements in the range of 0.459 to 0.796 . These results indicate that the instrument is valid based on validity test.

To measure the reliability we use theAlpha coefficient of each variable, the result shows that each variable are in the range 0.606 to 0.794 .These results indicate that all the variables in this study is reliable.

\section{Hypothesis Test Results}

Based on the results of research data is processed and calculated using SPSS program. The results obtained as in Table 1.

Table 1 Summary of Results of Multiple Regression Analysis

\begin{tabular}{lccc}
\hline \multicolumn{1}{c}{ Variable } & $\begin{array}{c}\text { Standardized } \\
\text { CoefficientsBeta }\end{array}$ & $\begin{array}{c}\mathrm{t}- \\
\text { test }\end{array}$ & Sig. \\
\hline Competency $\left(\mathrm{X}_{1}\right)$ &, 370 & 4,240 &, 000 \\
Understanding of &, 236 & 2,456 &, 016 \\
SAP $\left(\mathrm{X}_{2}\right)$ & & & \\
Implementation &, 228 & 2,505 &, 014 \\
SPI $\left(\mathrm{X}_{3}\right)$ & & & \\
\hline$F_{\text {test }}=28,435$ & & & \\
Signifikansi $=0,000$ & & & \\
Adjusted $R^{2}=0,449$ & & \\
$\alpha \quad=0,05$ & & \\
\hline
\end{tabular}

Table 1 shows that the F-test for the effect of competence, understanding of government accounting standards and the implementation of internal control systems affect the quality of financial reporting was significant $\left(\mathrm{F}_{\text {test }}=28.435\right.$; sig. $\left.=0.000\right)$. Based on the result of multiple linear regression calculation from SPSS application, then regression equation that can be formed that is:

$$
\mathrm{Y}=0.370 \times 1+0.236 \times 2+0.228 \times 3+e
$$

The equation shows that competence, understanding of government accounting standards and the implementation of internal control system have a positive and 
significant impact on the quality of financial statements. That is, the increased competence, understanding of government accounting standards and the implementation of internal control system the more qualified financial statements produced by financial managers in regional work stations in Kepahiang District.The coefficient of influence of competence variable is highest among other variables (0.370) while the understanding of accounting standards and the application of internal control system are $(0,236$ and 0,228$)$.

The contributions these three variables on the quality of financial reporting is high, which is 45 percent (Adj $\mathrm{R}^{2}=0.449$ ). While the rest, 55 percent, the quality of financial statements influenced by the other factors despite of competence, the understanding of government accounting standards and the implementation of internal control system.

Table 1 shows that there is simultaneously a significant influence between competence, understanding of accounting standards and the application of internal control system of the quality of financial statements $\left(\mathrm{F}_{\text {change }}=28.435 ; \rho\right.$ value $\left.=0.000\right)$. Thus, the first hypothesis $\left(\mathrm{H}_{1}\right)$ is supported $(\mathrm{P}<0.05)$. We state that the more competent, the more understand the government accounting standards and can apply the internal control system together to give a significant effect on the quality of financial statements.

The result of statistic analysis shows that the competency significantly affect the quality of financial reports ( $\mathrm{t}_{\text {test }}=4.240 ; \square=0.000$ ). Because the value of $\square<0.05$, we conclude that the second hypothesis $\left(\mathrm{H}_{2}\right)$ is supported. The results of this test interpret the competence variables significantly influence the quality of financial statements. This means that the higher the competence will be the more qualified financial statements generated.

The result of the third hypothesis $\left(\mathrm{H}_{3}\right)$ indicate that government accounting standards understanding effect the quality of financial reports significantly $\left(\mathrm{t}_{t e s t}=2.456\right.$; $\square \square$ value $=0.016$ ). Because the value of $\square$ value $<0.05$, we conclude that the third hypothesis $\left(\mathrm{H}_{3}\right)$ is supported.The results of this test interpreted that the variable understanding of accounting standards have a significant effect on the quality of financial statements.This means that the higher the level of understanding of accounting standards will be the more qualified financial statements generated.

The results of data analysis states that the fourth hypothesis testing $\left(\mathrm{H}_{4}\right)$, namely the implementation of internal control systems significant effect on the quality of financial reports ( $\mathrm{t}_{\text {test }}=2.505 ; \square=0.014$ ). Because the value of $\square<0.05$, we conclude that the fourth hypothesis $\left(\mathrm{H}_{4}\right)$ is supported.The results of this test interpret that the variables of internal control system implementation significantly influence the quality of financial statement information. This means that the higher the application of internal control system will be more qualified financial reports generated.

\section{Discussion}

According to (Arens et al., 2008) internal controls are designed and implemented by management to be reasonable ensure organizational objectives will be achieved. The benefit of internal control application is to provide reasonable assurance on the achievement of organizational goals through effective and efficient activities, reliability of financial reporting, security of state assets and compliance with laws and regulations. The understanding of government accounting standards and the application of internal control systems also influence the quality of financial statements. Regional government financial manager already has an understanding of the applicable government accounting standards. This can be seen from the answers of respondents in answering each question by obtaining the average value in the category of understand.The understanding of government accounting standards owned by regional work stations financial managers has been able to distinguish revenue recognition by, presentation of expense recognition, and determination of depreciation of property and equipment. Financial managers are able to record and present accounting transactions in accordance with the rules. 
Xuet al.(2003) propose factors that affect the quality of financial statements are human resources, systems, organizations and external factors. While supporting the achievement of quality financial statements, the organization must provide human resources competencies, relevant accounting standards, implementation of supervision and control, and working mechanisms within the organization (Mardiasmo, 2009).Research conducted by Wati et al.(2014) explains that the competence and application of government accounting standards have a significant effect on the quality of financial statements.

The result of regression analysis and hypothesis test shows that competence, understanding of government accounting standard and internal control system implementation significantly influence the quality of financial report produced by manager at every station of regional government in Kepahiang. Where competence has the highest contribution in affecting the quality of financial statements. Competencies of regional financial manager in Kepahiang Regency can be interpreed as highly competent in producing financial statements. This can be seen from the opinion of BPK on the financial reports of local governments that obtain WTP opinion. Regional financial manager at Kepahiang Regency in presenting the financial statements is using government accounting standard, where the government accounting standard which is valid since 2015 is accounting standard of government based on accrual.

According to Hitt et al. (1999) competency is a combination of knowledge, skills, attitudes and experience. Regional financial manager are known to have knowledge, ability, and behavior to achieve the government's goal of compiling and presenting quality financial report. Knowledge of the financial manager is the ability to prepare financial statements. Knowledge in preparing financial statements is supported by the knowledge gained from the formal level. This can be seen from the characteristics of respondents who majority have undergraduate education background S-1, so that in the application of applicable accounting standards can be quickly understood and applied.As it has the ability possessed by regional work stations financial managers in preparing financial statements already have the ability to operate financial applications. Kepahiang Regency has been using the appropriate financial applications that BPKP. So in the use of financial applications only require more ability in following the development of the financial application version. Furthermore, the research conducted by Nagor et al.(2015) shows that the implementation of internal control system affect the quality of local government financial statements. We suggest that the future research use the experiment methods that specifically analyze the precedence and antecedent of financial report quality and also comparing the financial report of public and private sector.

\section{CONCLUSION}

This study offers theoretical and practical implication on the implementation of internal control system in producing quality financial report that can be applied continuously for the regional financial managers. According to Bastian (2001) qualified financial statements can not present by itself. A quality financial report of course can not be separated from good financial management. Good financial management is an early reflection that financial reporting is well presented. A good financial manager can be interpreted as a financial manager who has the competence so as to present high quality of financial reports.

In the preparation of financial statements, financial managers have been able to enforce appropriate actions in the event of any deviation from policies, procedures or violations of applicable rules, to identify and manage risks so as to minimize failure in presenting financial statements and to follow up on any findings / reviews And advice given by the inspectorate / BPK, may evaluate the findings / reviews and suggestions for improvement in the preparation of the financial statements. Based on the results of research and discussion we drawn the following conclusions: 
1. Competence positive and significant impact on the quality of the financial statements, so the more competent financial manager it will be the quality of financial reports generated.

2. Comprehension government accounting standards and significant positive effect on the quality of financial statements, thus increasing the level of understanding of government accounting standards, the more the air quality of the resulting financial statements.

3. The implementation of internal control systems and a significant positive effect toward the quality of financial statements, thus increasing $\mathrm{p}$ Application of the internal control system, the more the air quality of the resulting financial statements.

Competence, comprehension government accounting standards and the application of systems internal control simultaneously positive and significant impact on the quality report finance. That is, if competence, understanding of government accounting standards and the application of systems internal control will influence enhancement quality report finance.

\section{References}

Arens, A. A., Elder, J. ., \& Beasley, S. M. (2008). Auditing and Assurance Service an Integrated Approach. 12th Edition. Upper Sadel River. New Jersey: Pearson Education International.

Basley, J. D., Nikolai, L. A., \&, Jones, J. P. (2007). Intermediate Accounting. 9th Edition. Thomson, South-Western.

Bastian, I. (2001). Sistem Akuntansi Sektor Publik di Indonesia. Jakarta: Salemba Empat

Biddle, G. C., Hillary, G., Verdi, R. S. (2009). How Does Financial Reporting Quality Relate to Investment Efficient. Journal of Accounting and Economics 48.

Beest, F. V., Braam, G., \& Boelens, S. (2009). Quality of Financial Reporting: Measuring Qualitative Characteristics. Nijmegan Center for Economics (NiCE) Institute for Management Research, Radboud University Nijmegen. http://www.ru.nl/nice/workingpapers.

Enceng; liestyodono dan Purwaningdyah. (2008). Meningkatkan Kompetensi Aparatur Pemerintah Daerah Dalam Mewujudkan Good Governance. Jurnal Kebijakan Dan Manajemen PNS. Pusat Pengkajian \& Penelitian Kepegawaian BKN.

Fikri, M. A., Inapty, B. A., \& Martiningsih, S. P.. (2015). Pengaruh Penerapan Standar Akuntansi Pemerintahan, Kompetensi Aparatur Dan Peran Audit Internal Terhadap Kualitas Informasi Laporan Keuangan Dengan Sistem Pengendalian Intern Sebagai Variabel Moderating. Simposium Nasional Akuntansi 18. Medan: Universitas Sumatera Utara

Halim, A., \& Kusufi, M. S. (2014). Akuntansi Sektor Publik. Jakarta: Salemba Empat

Hitt, M., \& Irlandia, R. D. (1999). Strategic Management: Competitiveness \& Globalization. Cengage Learning. 10th Edition.

Hilton, R. W., Michael, W. M., \& Frank, H. S. (2000). Cost Manajemen, Strategies for Business Decision. International Edition. McGraw-Hill Companies, Inc.

Hutapea, P., \& Nurianna, T. (2008). Kompetensi Plus. Jakarta: PT. Gramedia Pustaka Utama. 
Indriasih, D. (2014). The Effect of Government Apparatus Competence and the Effectiveness of Government Internal Control Toward the Quality of Financial Reporting in LocalGoverment. Research Journal of Finance and Accounting. Vol.5

Jonas, G. J., \& Blanchet, J. (2000). Assessing Quality of Finacial Reporting. Accounting Horizon 14(3), 353-363.

Mardiasmo. (2009). Akuntansi Sektor Publik. Yogyakarta: Andi.

Nagor, T. F., Darwanis., \& Abdullah, S. (2014). Pengaruh Penerapan Sistem Pengendalian Intern dan Prinsip Pengelolaan Keuangan Daerah Terhadap Kualitas Laporan Keuangan. Jurnal Magister Akuntansi Pasca Sarjana Universitas Syiah Kuala 4(1).

Nuraini, H., \& Sumiyati, E. E. (2014). Pengaruh Penerapan Standar Akuntansi Pemerintah Terhadap Kualitas Laporan Keuangan. Seminar Nasional Ekonomi dan Bisnis (SNEB).

Putri, N. K. R., Darmawan, N., \& Werastuti, D. N. (2015). Pengaruh Kualitas Sumber Daya Manusia Bidang Akuntansi Dan Sistem Pengendalian Internal Terhadap Kualitas Laporan Keuangan. E-Journal Universitas Pendidikan Ganesha 3(1)

Sari, N. P., Adiputra., \& Sujana, E. (2014). Pengaruh Pemahaman Standar Akuntansi Pemerintah dan Pemanfaatan Sistem Informasi Akuntansi Keuangan Daerah Terhadap Kualitas Laporan Keuangan Pemerintahan Daerah. e-Jurnal Akuntansi Universitas Pendidikan Ganesha 2(1).

Sekaran, U. (2010). Research Methods for Business: A Skill Building Approach. New Jersey: John Willey \& Son.

Sudiarianti, N. M., Ulupui, I. G. K. A., \& Budiasih, I. G. A. (2015). Pengaruh Kompetensi Sumber Daya Manusia Pada Penerapan Sistem Pengendalian Intern Pemerintah Dan Standar Akuntansi Pemerintah Serta Implikasinya Pada Kualitas Laporan Keuangan Pemerintah Daerah. Simposium Nasional Akuntansi 18. Medan: Universitas Sumatera Utara.

Tang, Q., Chen, H., \& Zhijun, L. (2008). Financial Reporting Quality and Investor Protection: A Global Investigation. working paper.

Tanjung, A. H. (2013). Akuntansi Pemerintahan Daerah Berbasis Akrual Pendekatan Teknis Sesuai PP No.71/2010. Cetakan 2. Bandung: Alfabeta

Wahyono, T. 2004. Sistem Informasi Akuntansi: Analisis, Desain dan Pemograman Komputer. Yogyakarta: Penerbit Andi.

Wati, K. D., Herawati, N. T., \& Sinarwati, N. K. (2014). Pengaruh Kompetensi SDM, Penerapan SAP dan Sistem Akuntansi Keuangan Daerah Terhadap Kualitas Laporan Keuangan Daerah. e-Jurnal Akuntansi 2(1)

Wibowo. (2014). Manajemen Kinerja. Jakarta: PT.Grafindo Parsada

Zikmund, W.G. (2010). Business Research Method. Fort Worth: Harcourt Brace Jovanovich College Publishers.

Xu, H., Jeretta, H. N., Nord, G. D., \& Lin, B. (2003). Key Issues of Accounting Information Quality Management: Autralian Case Study. Industrial Management and Data System. Vol 103. Issue 7. 